\title{
Corporate Growth Strategies, External Operating Environment and Firm Performance: An Empirical Survey of Large Manufacturing Firms in Nairobi City County, Kenya
}

\author{
Alexander Irungu Wanjiru ${ }^{1}$, Stephen Makau Muathe ${ }^{1} \&$ Jane W.Kinyua-Njuguna ${ }^{1}$ \\ ${ }^{1}$ Department of Business Administration, School of Business, Kenyatta University, Kenya \\ Correspondence: Alexander Irungu Wanjiru, Department of Business Administration, School of Business, Kenyatta \\ University, Kenya, P.O Box 8903-00100, Nairobi, Kenya. Tel: 254-721-684-072.
}

Received: July 6, 2019

Accepted: July 25, 2019

Online Published: July 29, 2019

doi:10.5430/jms.v10n4p21

URL: https://doi.org/10.5430/jms.v10n4p21

\begin{abstract}
Theoretical literature in strategic management describes performance as outcome of firm's strategic objectives, which are developed and executed at the corporate level of management. Conceptual propositions also suggest that the external operating environment of a firm influences the relationship between its corporate strategies and performance. This paper examines the direct effect of corporate growth strategies on performance of large manufacturing firms in Nairobi City County, Kenya. The strategies under study are market development, product development and diversification. The paper also examines the moderating effect of external operating environment on the relationship between corporate growth strategies and performance of the large manufacturing firms. The authors adopted indicators of competitive position, consumer behaviour and credit accessibility to measure external operating environment.Multistage probability sampling technique was used to select study sample of 189 firms. One hundred forty eight firms responded where primary data was collected using a semi-structured questionnaire. Data was analysed using descriptive and inferential statistics. The study findings indicate that corporate growth strategies have a positive and significant impact on a firm's performance. It also found out that external operating environment has a moderating effect on the relationship between corporate growth strategies and firm performance. The study has important implications for managers and policy makers of the manufacturing firms.
\end{abstract}

Keywords: corporate growth strategies, external operating environment, manufacturing firms, moderating effect, firm performance

\section{Introduction}

Extant theoretical arguments in strategic management posit that firm resources and capabilities are important in determining the nature of strategies to use. According to Porter (2008); Kutllovci, Shala and Troni (2012) corporate strategies include the firm intention to maintain its current position; achieve high growth as compared to current achievements or aim at reducing its one or more business operations. Wheelen and Hunger (2008) contend that among the corporate strategies, growth strategies which include market development, product development and diversification might be more applicable in an operating environment dominated by scarcity of resources as well as uncertainty of market and consumer behaviour. The context of this study is sub-Saharan Africa that is known to experience challenges in resource availability, distribution and prudent exploitation.

The concept of firm performance has been addressed in most strategic management studies as outcome of three factors, which are strategy (Mazdeh, Moradi \& Mazdeh, 2011); competitive advantage (Hosseini \& Sheikh, 2012); and environment (Tan \& Liu, 2014). Firms operate within external environment constituting varied factors that determine performance. According to Neneh and Vanzyl (2014) firm external operating environment include forces some of which the management cannot control thus bringing forth threats and opportunities in equal measures to the firm. This is consistent with Porter's (2008) views that the organization's threats and opportunities originate from the external operating environment. Some of the external factors include; competitive position, consumer behaviour, market changes and credit availability (Spanos, Zaralis \& Lioukas, 2004; Pearce \& Robinson, 2013). Therefore, firm strategies should be adequate to fit into the external operating environment so as to efficiently enhance performance (Eljelly, 2004; Padachi, 2006). However, according to Filbeck and Krueger (2005); Raheman and Nasr (2007) 
existing external operating environment in developing countries may be restrictive towards firm performance.

\subsection{Research Problem and Objectives}

Jarzabkowski (2008) suggested that firms might require corporate growth strategies to predict and explain the established behaviour within their environments to remain competitive and enhance performance. The empirical analysis of corporate growth strategies show that there exists no well-conceptualized framework of the determinants of the effect of these strategies on firm performance. According to Momoh (2012), empirical studies have been reported in other African countries like Nigeria regarding effect of corporate strategies on performance of manufacturing firms. However, the moderating effect of external operating environment on this relationship is not well documented. The study by Rukia, Mukulu, Kihoro and Waiganjo (2015) on manufacturing firms in Kenya focused on business strategies. Likewise, Kyengo, Ombui and Iravoin (2016) studied the effects of firm business strategies on performance of telecommunication firms in the Kenyan context. Research gaps in these studies arise from the opinion that manufacturing operations and business activities must originate and be consistent with firm's corporate strategies in order to acquire superior performance.(Chase, Aquilano, Nicholas \& Jacobs, 2004; Oltra \& Flor, 2010).

The previous studies have not provided adequate evidence on the moderating effect of operating environment on corporate strategies and performance of manufacturing firms in the Kenyan context. In addition, llittle attention has been paid to the impact that corporate growth strategies has within large manufacturing firms. Furthermore, studies have dealt with single industries and no prior study has focused on the firms across industries. Based on foregoing arguments, there exists contextual, conceptual and empirical gap in the existing literature regarding corporate growth strategies and performance of manufacturing firms. Therefore, the main objective of the study was to investigate the effect of corporate growth strategies on the performance of large manufacturing firms in Nairobi City County, Kenya.

\section{Literature Review}

\subsection{Theoretical Review}

Various authors advance different propositions of firm performance based on the theory adopted in describing performance. The Resource Based View (RBV) theory was one of the theories adopted in this study to describe performance of manufacturing firms. The RBV of the firm suggests that the firm resources and core competencies fundamentally determine its strategies (Pearce \& Robinson, 2007). According to Peteraf and Bergen (2003); Hodgson (2008) for a firm to arrive at a better determined corporate strategy, it is important to conceive its resources as capacities towards superior performance. Therefore, firm corporate strategies can be established by focusing on integration of firm strategic resources and capabilities (Furrer, Thomas \& Goussevskaia (2008).

The study also adopted institutional theory and resource-dependency theory to describe firm external operating environment. The institutional theory postulates that institutional pressures lead organizations to adopt structures, strategies, and processes in order to reduce environmental uncertainty (Scott, 1995). This theory posits that organizational adaptation is important because a mismatch between organizational strategies and the operating environment can lead to misfit between organizational goals and the market expectation (Greenwood, Oliver, Suddaby \& Sahlin 2008). The Resource Dependency theory posits that the firm's key determinant of performance will be contingent on its resources and the external environment (Hillman, Cannella \& Paetzold, 2000). The theory mainly focuses on the dependency of the firm on the environment for critical resources that lead to successful performance (Chin, Widing \& Paladino, 2004). The theory postulates that superior organizational performance may result from managing uncertainty and choosing the appropriate strategies to proactively influence the external operating environment to the advantage of the organization (Davis \&Cobb, 2010).

\subsection{Empirical Review}

Empirically, several studies have demonstrated effect of corporate growth strategies on performance. Studies by Faria and Wellington (2005); Yuan, Feng and Liu (2006); Kittichai and Phapruke (2010) showed that market development strategy had positive and significant effect on firm performance. Likewise, Isidre, Gunasekaranb and Begoña (2002); Amue and Adiele (2012) and Kavale, Mugambi and Namusonge (2016) found that product development strategy positively and significantly affected firm performance. Lee, Hall and Rutherford (2003); Chia, Wen and Heng, (2008); Iwona and Bielawska (2010); Ezzi and Jarboui (2015) found that diversification strategy had positive and significant effect on firm performance. Other empirical studies have shown positive and significant effect of external operating environment on the relationship between corporate growth strategies and firm performance. Such studies include, Henk, Niels, Ernst, Marten and Antonio (2012); Hsiang, Hsien and Dja-Shin (2012); Adeoye and Elegunde (2012), and 
Hidayat, Sabarudin and Mu'alim (2015).

\subsection{Conceptualization and Hypotheses}

The conceptual framework is developed from the study theoretical and empirical literature reviews. The study conceptualize that effect of corporate growth strategies on firm performance is moderated by external operating environment.

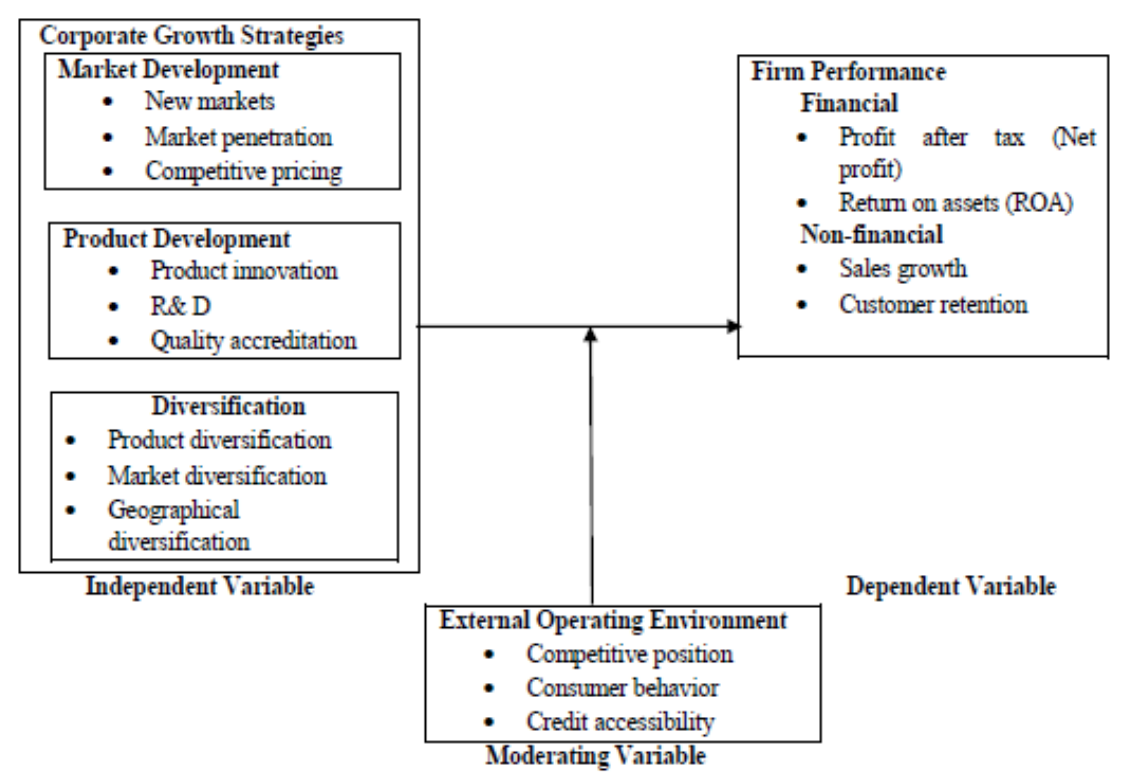

Figure 1. Conceptual framework

Whereas the corporate strategies of a firm are varied, there is a consensus among scholars of strategic management that corporate growth strategies are important determinants of firm performance. The corporate growth strategies intention is to help the firm attain high performance as compared to current achievements (Porter, 2008; Kutllovci, Shala \& Troni, 2012; Pearce \& Robinson, 2013). In addition, firm corporate growth strategies are drawn and executed based on firm's environmental context. From the conceptual framework, two hypotheses were stated as follows:

$\mathrm{H}_{01 \text { : }}$ Corporate growth strategies have no effect on performance of manufacturing firms in Nairobi City County, Kenya.

$\mathrm{H}_{02}$ : External operating environment has no moderating effect on the relationship between corporate growth strategies and performance of manufacturing firms in Nairobi City County, Kenya.

\section{Methodology}

\subsection{Research Design and Population}

The study adopted both descriptive and explanatory survey designs as recommended by Sekaran and Bougie (2009). The descriptive and explanatory survey designs enable studies to test hypotheses quantitatively (Njuguna, Munywoki $\&$ Kibera, 2014). Additionally, the use of more than one research design triangulate research findings raising validity of the results ( Saunders, Lewis and Thornhill ,2009).The descriptive design helped the study to capture the characteristics of the population and study variables in their natural situation (Cooper \& Schindler, 2003; Burns \& Grove, 2007). Explanatory design was used to explain relationships between variables (Kothari, 2004).

The study targeted 373 manufacturing firms based in Nairobi City County, Kenya categorised as large by the Kenya Association of Manufacturers. Out of the target population, a sample size of 189 firms was obtained through multi-stage sampling method as recommended by Shapiro, Carlson, Astin, and Freedman (2006). The steps of determining sample size was proportionate stratified sampling defined by sub- sector, which are categorized by what they produce (KAM, 2016). A sample size of 184 firms was used in the current study which was arrived at using the 
formula suggested by Fisher, Laing and Stoeckel (1985) as follows:
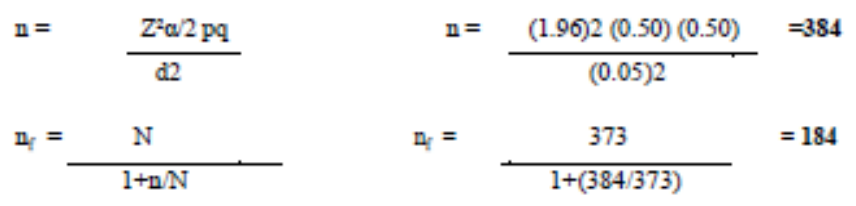

Where:

$\mathrm{n}_{\mathrm{f}}=$ is the desired sample size (when the population is less than 10,000).

$\mathrm{N}=$ the Population (in this case 373 firms).

$\mathrm{n}=$ the desired sample size (if the target population is greater than 10,000)

$\mathrm{z}=$ the degree of confidence (in this case $95 \%$ confidence interval, $\alpha=1.96$ )

$\mathrm{p}=$ the proportion in the target population estimated to have characteristics being measured. $50 \%$ chosen as recommended by Fisher et al., (1985)

$\mathrm{d}=$ the level of statistical significance (set at $5 \%$ ).

Finally, a simple random sampling was conducted to select specific firms to participate in the study with chief executive officers/managing directors as the units of observation. Foya, Kilika and Muathe (2015) used the multistage sampling method in their study.

\subsection{Data Collection and Analysis}

The study used a self-administered questionnaire for collection of primary data. The questionnaire consisted of semi-structured questions that had been designed to address both the general and specific objectives of the study. One hundred and forty eight questionnaires were received back which translated to a response rate of $80.43 \%$. The study instrument was subjected to a panel of experts to determine the content validity. Confirmatory factor analysis (CFA) was used to investigate construct validity of the instrument as recommended by Patton (2002). According to Rahim and Magner (2005)an instrument is said to fulfil construct validity when Eigen values are greater than 1.0 and loadings greater than 0.4 . Therefore, the research instrument had adequate construct validity since all the items had Eigen values greater than 1.0 and loadings greater than 0.4.A pilot study using 20 respondents who were part of the study population was done to test for reliability of research instrument.

From the conceptual framework, firm performance is a function of composite variable corporate growth strategies whose components are market development, product development and diversification. Hence;

$$
\mathrm{Y}=\beta_{0}+\beta_{1} \mathrm{X}_{1}+\beta_{2} \mathrm{X}_{2}+\beta_{3} \mathrm{X}_{3}+\varepsilon
$$

Where;

$\beta_{0}=$ Constant (intercept)

$\beta_{1}, \beta_{2}$ and $\beta_{3}=$ Beta coefficients of independent variable

$\mathrm{X}_{1}=$ Market development strategy

$\mathrm{X}_{2}=$ Product development strategy

$\mathrm{X}_{3}=$ Diversification strategy

$\varepsilon=$ Error term

Moderation was tested by determining statistical significance of coefficient for the interaction term as recommended by Whisman and MacClelland (2005). Therefore, models 2, 3 and 4 were estimated as follows;

$$
\begin{gathered}
Y=\beta_{0}+\beta_{1} X_{1}+X_{2}+X_{3}+\varepsilon \\
Y=\beta_{0}+\beta_{4} C S+\beta_{5} E O E+\varepsilon
\end{gathered}
$$

(Model 3)

Where;

$\mathrm{Y}=$ Firm performance

$\beta_{0}=$ Constant (intercept)

$\beta_{4}$ and $\beta_{5}=$ Beta coefficients 
$\mathrm{CS}=$ Composite index for market development, product development and diversification

$\mathrm{EOE}=$ External operating environment

$\varepsilon=$ Error term

Model 4 was used to provide the direction and effect of the external operating environment on corporate growth strategies and the total effect of the moderator on firm performance by showing the interaction between operating environment and corporate growth strategies. The model was as follows;

$$
\mathrm{Y}=\beta_{0}+\beta_{4} \mathrm{CS}+\beta_{6} \mathrm{CS} * \mathrm{EOE}+\varepsilon
$$

(Model 4)

Where;

Y= Firm performance

$\beta_{0}=$ Constant

$\beta_{4}$ and $\beta_{6}=$ Beta coefficients

$\mathrm{CS}=$ Composite index for market development, product development and diversification

$\mathrm{CS} * \mathrm{EOE}=$ Corporate growth strategies $\mathrm{x}$ External operating environment

$\varepsilon=$ Error term

The decision-making criteria for moderation are summarized in Table 1.

Table 1. Moderation decision making criteria

\begin{tabular}{llll}
\hline Model 3 & Model 4 & Total effect & Conclusion \\
\hline$\beta_{4}$ is not significant $(\mathrm{p}>0.05)$ & - & - & No moderation \\
\hline$\beta_{4}$ is significant $(\mathrm{p}<0.05)$ & $\beta_{6}$ is not significant $(\mathrm{p}>0.05)$ & - & $\begin{array}{l}\text { Moderating variable is an } \\
\text { explanatory variable }\end{array}$ \\
\hline$\beta_{4}$ is significant $(\mathrm{p}<0.05)$ & $\beta_{6}$ is significant $(\mathrm{p}<0.05)$ & $\beta_{3}$ & $\begin{array}{l}\text { Moderating variable has a } \\
\text { moderating effect }\end{array}$
\end{tabular}

Source: Whisman and MacClelland (2005)

\section{Results}

Out of the 184 issued questionnaires, 36 were not responded to, while148 were properly filled and returned translating to a response rate of $80.43 \%$. According to Mugenda and Mugenda (2003) a response rate of 50\% and above is satisfactory hence this response rate was satisfactory.

\subsection{Descriptive Analysis}

\subsubsection{Background Characteristics}

The study findings are shown in Table 2.

Table 2. Firm background characteristics

\begin{tabular}{llll}
\hline Category & Sub-Category & Frequency & Percentage \\
\hline Age of the firm(Years) & $21-30$ & 20 & 13.5 \\
\hline & 41 to 50 & 86 & 57.8 \\
\hline & Above 50 & 22 & 28.7 \\
\hline Size of the firm (Assets Value) & Total & $\mathbf{1 4 8}$ & $\mathbf{1 0 0}$ \\
\hline & Above Kshs. 100 Million & 148 & 100 \\
\hline & Total & $\mathbf{1 4 8}$ & $\mathbf{1 0 0}$
\end{tabular}

Source: Survey data (2018) 
Based on research findings presented in Table 2, eighty six firms (57.8\%) had been in existence for a period between 41 and 50 years, more than 50 years were twenty two (28.7\%), twenty firms $(13.5 \%)$ were found to have existed for a period between 21-30 years. The respondents indicated that all the manufacturing firms were large under classification by Kenya Association of Manufacturers (KAM). This finding was not unusual since according to KAM, large firms have been in existence for long period to achieve annual turnover of $\$ 100 \mathrm{M}$, thus; more likely to sustain operations by dominating production and market shares, at the same time attracting investors for capital injection based on the perception that large firms are more profitable.

\subsubsection{Corporate Growth Strategies}

The study investigated the three components of the independent variable shown in Table 3.

Table 3. Corporate growth strategies

\begin{tabular}{lll}
\hline Variable & Mean & Standard Deviation \\
\hline Market Development Strategy & 3.67 & 1.04 \\
\hline Product Development Strategy & 3.66 & 1.07 \\
\hline Diversification Strategy & 3.59 & 1.08 \\
\hline Aggregate & $\mathbf{3 . 6 4}$ & $\mathbf{1 . 0 6}$ \\
\hline
\end{tabular}

Source: Survey data (2018)

The findings in Table 3 show that market development strategy was the most practised by the manufacturing firms with a mean of 3.67 and standard deviation of 1.04, followed by product development strategy with a mean of 3.66 and standard deviation of 1.07, and least used was diversification strategy at a mean of 3.59 and standard deviation of 1.08 .

\subsubsection{External Operating Environment}

Three components of the moderating variable namely competitive position, credit accessibility and consumer behaviour were studied as shown in Tables 4,5 and 6 .

\subsubsection{Competitive Position}

The respondents rated firm competitive position as a component of external operating environment on a Likert type scale of $1-5$, where strongly agree $=5$, Agree $=4$, Disagree $=3$, strongly disagree $=2$ and Not at all $=1$. The findings are shown in Table 4.

Table 4. Descriptive statistics of competitive position

\begin{tabular}{lll}
\hline Statement & Mean & Std. Deviation \\
\hline Firm competitive position is restricted by industry competition & 4.13 & 0.890 \\
\hline Firm competitive position is restricted by lack of industry infrastructure & 3.77 & 0.984 \\
\hline Firm competitive position is threatened by new industry entrants & 3.86 & 1.190 \\
\hline Firm competitive position is negatively affected by industry entry barriers & 3.84 & 1.123 \\
\hline Firm competitive position is threatened by substitute products & 3.80 & 1.060 \\
\hline $\begin{array}{l}\text { Firm competitive position is restricted by lack of related and supporting } \\
\text { internationally competitive industries }\end{array}$ & 3.78 & 1.072 \\
\hline $\begin{array}{l}\text { Firm competitive position is restricted by lack of government's supportive } \\
\text { business environment }\end{array}$ & 3.57 & 1.017 \\
\hline $\begin{array}{l}\text { Firm competitive position is negatively affected by bargaining power of } \\
\text { customers }\end{array}$ & 3.64 & 1.155 \\
\hline Average & $\mathbf{3 . 8 0}$ & $\mathbf{1 . 0 6}$ \\
\hline
\end{tabular}

Source: Survey data (2018) 
The findings in Table 4 indicate that the manufacturing firms' competitive position is mainly restricted by industry competition, threatened by new industry entrants and negatively affected by industry entry barriers. Despite the effects of other factors restricting the firm competitive position, lack of government's supportive business environment, bargaining power of customers, and lack of industry supporting infrastructure least affect the firm competitive position. The aggregate mean score round off to a score of 4 on the five point Likert type scale implying that the respondents agreed that the firm's external operating environment (competitive position) affect relationship between corporate strategies and performance. The findings agreed with Hidayat, Sabarudin and Mu'alim (2015) study, which established that external environment, affected corporate strategies and performance of manufacturing industries in Indonesia.

\subsubsection{Credit Accessibility}

The respondents rated firm credit accessibility as a component of external operating environment on a Likert type scale of $1-5$, where strongly agree $=5$, Agree $=4$, Disagree $=3$, strongly disagree $=2$ and Not at all $=1$. The findings are shown in Table 5.

Table 5. Descriptive statistics of credit accessibility

\begin{tabular}{lll}
\hline Statement & Mean & Std. Deviation \\
\hline Firm credit accessibility is restricted by government taxation regimes & 3.52 & 1.22 \\
\hline Firm credit accessibility is negatively affected by government fiscal policy & 3.46 & 1.214 \\
\hline $\begin{array}{l}\text { Government regulation of loan interest rates negatively affect firm's credit } \\
\text { accessibility }\end{array}$ & 3.29 & 1.132 \\
\hline $\begin{array}{l}\text { Unstable inflation and currency exchange rates negatively affect firm's credit } \\
\text { accessibility }\end{array}$ & 3.41 & 1.106 \\
\hline Firm's financial performance influences credit accessibility & 3.31 & 1.217 \\
\hline Firm credit accessibility is negatively affected by government domestic borrowing & 3.49 & 1.128 \\
\hline Firm performance is negatively affected by lack of global credit accessibility & 4.27 & 0.83 \\
\hline Average & $\mathbf{3 . 5 4}$ & $\mathbf{1 . 1 2}$ \\
\hline
\end{tabular}

Source: Survey data (2018)

The findings in Table 5 indicate that lack of global credit accessibility, government taxation regime; government domestic borrowing and fiscal policy are the main factors that negatively determine credit accessibility of the manufacturing firms. It shows that government regulation of loan interest rates and unstable currency exchange rates least affects firm credit accessibility. The aggregate mean score round off to a score of 4onthe five point likert scale implying that on average, the respondents agreed on effect of external operating environment (credit accessibility) on the relationship between corporate strategies and performance of manufacturing firms. The findings are consistent with a study byAdeoye and Elegunde (2012) which found that external operating environment affected the relationship between corporate strategies and performance of food and beverage manufacturing firms in Nigeria.

\subsubsection{Consumer Behaviour}

The respondents rated firm consumer behaviour as a component of external operating environment on a Likert type scale of $1-5$, where strongly agree $=5$, Agree $=4$, Disagree $=3$, strongly disagree $=2$ and Not at all $=1$. The results are shown in Table 6.

Table 6. Descriptive statistics of consumer behaviour

\begin{tabular}{lll}
\hline Statement & Mean & Std. Deviation \\
\hline Consumer behaviour determines demand for firm products & 3.64 & 1.23 \\
\hline Firm has corporate culture of responding to consumer behaviour & 3.44 & 1.10 \\
\hline Consumer perceptions determine the demand for our products & 3.50 & 1.23 \\
\hline
\end{tabular}




\begin{tabular}{lll}
\hline The performance of firm products is influenced by consumer habits & 3.39 & 1.12 \\
\hline The firm performance is negatively affected by varied preferences of consumers & 3.42 & 1.16 \\
\hline Consumer attitudes influence firm performance in the market & 3.47 & 1.13 \\
\hline Average & $\mathbf{3 . 4 8}$ & $\mathbf{1 . 1 6}$ \\
\hline
\end{tabular}

Source: Survey data (2018)

The findings in Table 6 indicate that demand for firm products, consumer perceptions and attitude were the main factors affecting the firm external operating environment. Results also indicated that consumer buying habits, preferences and consumer perceptions and lack of firm corporate culture in responding to consumer were factors that least determines the firm external operating environment. The aggregate mean score round off to a score of 3 on the five point Likert type scale, implying that on average, the respondents disagreed on effect of consumer behaviour on the relationship between corporate strategies and performance of manufacturing firms. The findings agreed with the study by Hsiang, Hsien and Dja-Shin (2012) establishing that not all factors in external operating environment has impact on relationship between corporate strategies and performance of Taiwan manufacturing firms.

Table 7. Summary of external operating environment

\begin{tabular}{lll}
\hline Component & Mean & Standard Deviation \\
\hline Competitive Position & 3.80 & 1.06 \\
\hline Credit Accessibility & 3.54 & 1.12 \\
\hline Consumer Behaviour & 3.48 & 1.16 \\
\hline Aggregate & $\mathbf{3 . 6 1}$ & $\mathbf{1 . 1 1}$ \\
\hline
\end{tabular}

Source: Survey data (2018)

Results illustrated in Table 7 show that on average the characteristics of competitive position had the biggest impact on the firms' external operating environment at a mean of 3.80 and standard deviation of 1.06. This was followed by credit accessibility at a mean of 3.54 and a standard deviation 1.12, while the consumer behaviour had the least impact with a mean of 3.48 and standard deviation of 1.16. On aggregate, the mean score of external operating environment round off to 4 on the five point Likert type scale, implying that the respondents agreed that external operating environment affects the relationship between corporate strategies and firm performance. These findings were consistent with studies by Hidayat, Sabarudin and Mu'alim (2015) which established that external environment, affected corporate strategies and performance of manufacturing industries in Indonesia. The findings supported study by byAdeoye and Elegunde (2012) which found that external operating environment affected the relationship between corporate strategies and performance of food and beverage manufacturing firms in Nigeria.

\subsection{Diagnostic Tests}

The Keiser-Meyer-Olkin (KMO) for sample adequacy was done, which obtained values greater than 0.5 as recommended by Malhotra and Dash (2011). Communalities and Eigen values were used in Confirmatory Factor Analysis to test for variable correlations, obtaining values that exceeded 0.4 meaning that no variables were highly correlated as recommended by Rahim and Magna (2005). The study found that all variables met normality threshold of values between -0.1 and +0.1 using Shapiro-Wilk test as recommended by Myoung (2008). The Pearson's correlation coefficients for all the independent variables were positive indicating positive linear relationship between individual independent variables and the dependent variable as recommended by Field (2009). Tolerance values for all variables were above 0.10 and VIF values of below 10 indicating that there was no multicollinearity as recommended by Field (2009). The test of homogeneity by use of Levene's test of homogeneity revealed the p-values for the three predictor variables were greater than the level of significance at .05 implying no homoscedasticity as recommended by Warner (2008).

\subsection{Results of Hypothesis Test}

$\mathrm{H}_{01}$ : Corporate growth strategies have no effect on performance of manufacturing firms in Nairobi City County, Kenya. 
Corporate growth strategies (predictor variable) were regressed against firm performance (dependent variable). To evaluate the effect of corporate growth strategies on performance, a model summary of the coefficient of determination was developed, and presented in Table 8 .

Table 8. Model summary

\begin{tabular}{llll}
\hline $\mathbf{R}$ & R Square & Adjusted R Square & Std. Error of the Estimate \\
\hline .697 & 0.486 & 0.475 & 0.26397 \\
\hline \multicolumn{2}{l}{ Predictors: (Constant), Diversification Strategy, Product Development Strategy, Market Development Strategy }
\end{tabular}

Source: Survey data (2018)

Findings in Table 8 shows an adjusted R-square value of 0.475 , which means that $47.5 \%$ of variation in firm performance can be explained by the three predictors that formed independent variable. The predictors were market development strategy, product development strategy and diversification strategy. The findings are consistent with the argument by Porter (2008) as well as the findings of a study by Kutllovci, Shala and Troni (2012) which indicated that corporate strategies positively influences firm performance. The findings for the ANOVA (Model fitness) are presented in Table 9.

Table 9. ANOVA results

\begin{tabular}{llllll}
\hline & Sum of Squares & df & Mean Square & F & Sig. \\
\hline Regression & 9.492 & 3 & 3.164 & 45.406 & .000 \\
\hline Residual & 10.034 & 144 & 0.07 & & \\
\hline Total & 19.526 & 147 & & \\
\hline Dependent Variable: Firm Performance & \multicolumn{5}{l}{$l$} \\
\hline \multicolumn{7}{l}{ Predictors: (Constant), Diversification Strategy, Product Development Strategy, Market Development Strategy } \\
\hline
\end{tabular}

Source: Survey data (2018)

The results in Table 9 on the amalgamated analysis of variance reveal an F statistic value of 45.406 which is significant at $5 \%$ level of significance $(\mathrm{Sig}=0.000$ ). The findings imply that the model linking corporate strategies to performance of manufacturing firms was of good fit and corporate strategies contribute significantly to changes in performance of manufacturing firms. These findings are consistent with the findings of a study by Monday, Akinola, Ologbenla and Aladeraji (2015) which showed that market development; product development and diversification strategies had significant effects on performance of Nigerian manufacturing firms. The findings for model coefficients are illustrated in Table 10.

Table 10. Regression model coefficients

\begin{tabular}{llllll}
\hline & \multicolumn{2}{l}{ Unstandardized Coefficients } & \multicolumn{2}{l}{ Standardized Coefficients } \\
\hline & B & Std. Error & Beta & T & Sig \\
\hline (Constant) & 0.331 & 0.275 & & 1.204 & 0.231 \\
\hline Market Development Strategy & 0.345 & 0.057 & 0.403 & 6.08 & 0.000 \\
\hline Product Development Strategy & 0.346 & 0.063 & 0.348 & 5.467 & 0.000 \\
\hline Market Diversification Strategy & 0.172 & 0.063 & 0.188 & 2.723 & 0.007 \\
\hline Dependent Variable: Firm Performance & & & & \\
\hline
\end{tabular}

Source: Survey data (2018) 


\section{Performance of large Manufacturing Firms $=0.331+0.345$ (Market Development Strategy) +0.346 (Product Development Strategy) + 0.172 (Market Diversification Strategy)}

Table 10 indicate the regression model coefficients of each indicator of corporate growth strategies that was included in the study; that is market development strategy, product development strategy and diversification strategy. The findings show that market development strategy has a beta coefficient of 0.345 and a p-value of 0.000 , which implies that it positively and significantly affects performance of the manufacturing firms. The findings imply that an increase in market development strategy by one unit leads to an increase in performance of manufacturing firms by 0.345 units. The results further imply that by focusing on market development strategy, manufacturing firms can achieve high performance. Based on these results, it can be concluded that manufacturing firms may determine their market depending on the particular segment's profitability and brand royalty among other factors. The findings are consistent with the findings of a study by Kittichai and Phapruke (2010) conducted on the relationship between market development and performance among garment industry in Thailand and established that market development impacted positively on firm performance in the garment industry in Thailand.

The findings further indicate that product development strategy has a beta coefficient of 0.346 and a p-value of 0.000 which implies that it positively and significantly affects performance of manufacturing firms. These findings imply that an increase in product development strategy by one unit leads to an increase in performance of manufacturing firms by 0.346 units. The results further imply that product development strategy contribute to firm performance. This would benefit the firms in developing broad range of products to offer market choices to address customer preferences, and manufacturing unique products to cope with industry competition. The findings agree with the findings by Isidre, Gunasekaranb and Begoña (2002) on product development and firm performance in manufacturing companies located in Spain that established a positive relationship between product development and firm performance.

On evaluation of diversification strategy, the findings revealed a beta coefficient of 0.172 and a p-value of 0.007 which implies that it positively and significantly affects performance of manufacturing firms. The findings imply that an increase in market diversification strategy by one unit leads to an increase in performance of manufacturing firms by 0.172 units. Based on these results, it can be argued that manufacturing firm focus on diversification would lead to benefits such as exploitation of emerging market opportunities and acquiring new customers from competitors through market control. The findings are consistent with the findings of a study by Ezzi and Jarboui (2015) that diversification affect performance of manufacturing firms in Tunisia.

$\mathrm{H}_{02}$ : External operating environment has no moderating effect on the relationship between corporate growth strategies and performance of large manufacturing firms in Nairobi City County, Kenya.

The hypothesis was tested using step-wise regression model as recommended by Whisman and MacClelland (2005). The first step involved regression of the composite index of corporate growth strategies measures (independent variable) on firm performance (dependent variable). In the second step, the composite index of corporate growth strategies measures and external operating environment (moderating variable) were regressed on the firm performance. In the third step, the composite index of corporate growth strategies measures, external operating environment and an interaction term were regressed on the firm performance measures. The regression results are presented in Tables 11, 12 and 13.

Table 11. Model summary on moderating effect

\begin{tabular}{lllll}
\hline Model & R & R Square & Adjusted R Square & Std. Error of the Estimate \\
\hline 1 & .687 & 0.472 & 0.468 & 0.26582 \\
\hline 2 & .800 & 0.64 & 0.635 & 0.22021 \\
\hline 3 & .821 & 0.674 & 0.667 & 0.21033 \\
\hline \multicolumn{4}{l}{ Predictors : Constant, Corporate Growth Strategies } \\
\hline \multicolumn{4}{l}{ Predictors : Constant, Corporate Growth Strategies, External Operating Environment } \\
\hline
\end{tabular}

Source: Survey data (2018) 
The results in Table 11 show adjusted R-square value of 0.468 for the model linking corporate growth strategies and firm performance. This indicates that $46.8 \%$ of firm performance was explained by corporate growth strategies. The findings also show that the adjusted $\mathrm{R}$ square value for the model linking corporate growth strategies and external operating environment to firm performance was 0.635 . This indicates that both corporate growth strategies and external operating environment explain up to $63.5 \%$ of the variation in firm performance up from $46.8 \%$ that only corporate strategies explained $(0.635>0.468)$. It was also established that, when the interaction term was fitted to the model of external operating environment and corporate growth strategies, a higher explanatory power on firm performance was obtained, as shown in the increase to $66.7 \%$ (Adjusted $\mathrm{R}^{2}=0.667>0.635>0.468$ ). This indicates that the moderating variable had high effect on the relationship between corporate strategies and firm performance. The findings are consistent with Hsiang, Hsien and Dja-Shin (2012) who established that external operating environment has substantial impact on the relationship between corporate strategies and firm performance.

Table 12. ANOVA for corporate growth strategies, external operating environment and firm performance

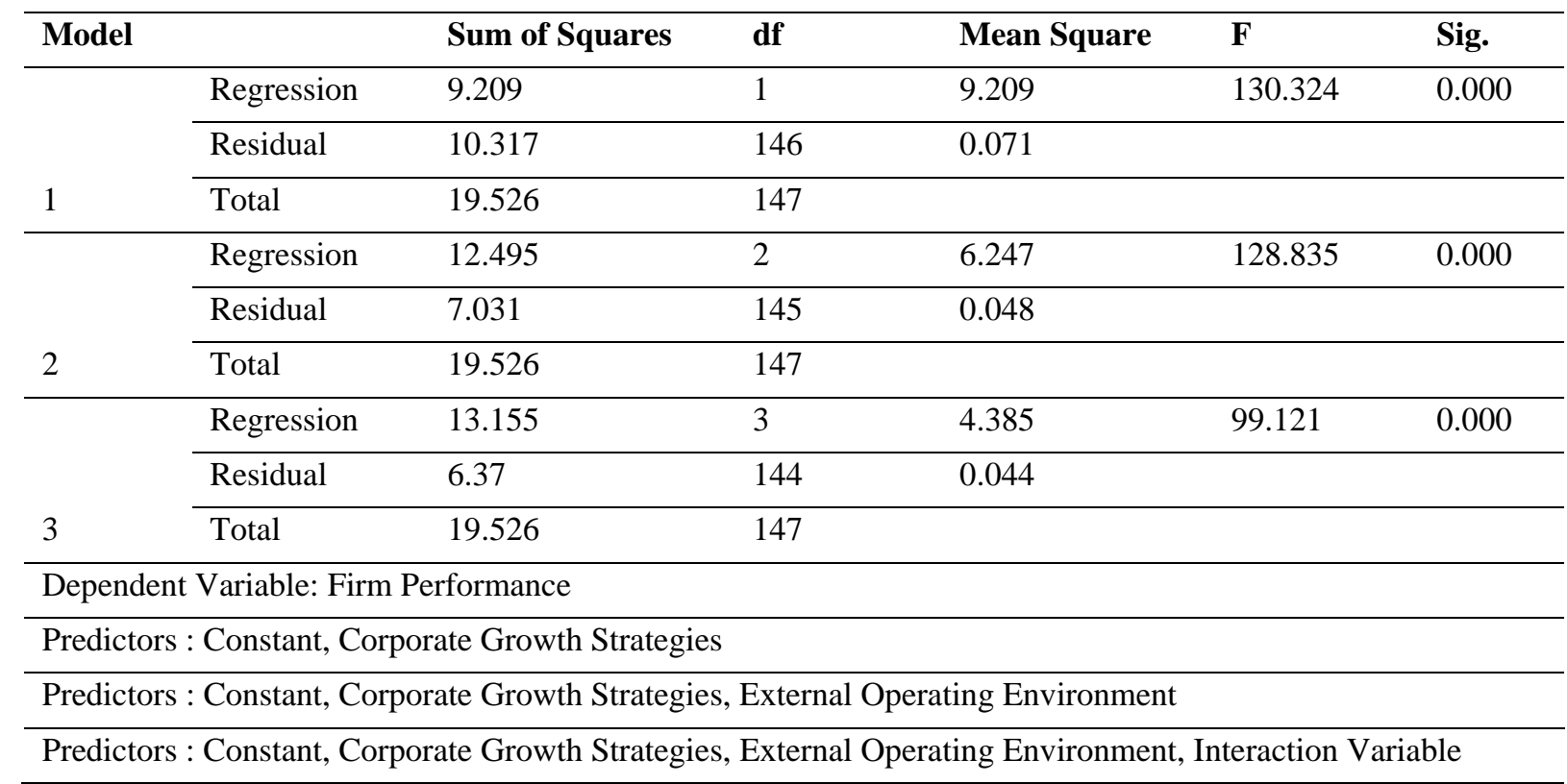

Source: Survey data (2018)

Table 12 shows an $\mathrm{F}$ statistic value of $(1,146)=130.324$ and $\mathrm{P}=0.000<0.05$ for the model linking corporate strategies to firm performance. This implies that the model linking corporate growth strategies to firm performance was significant. The findings also revealed an $F$ statistic of $F(2,145)=128.835$ and $p=0.000<0.05$ for the model linking corporate growth strategies and external operating environment to firm performance. This implies that the model linking corporate growth strategies and external operating environment to firm performance was significant. It was also established an F statistic of $F(3,144)=99.121$ and $p=0.000<0.05$ for the model linking corporate growth strategies, external operating environment and interaction term to firm performance. The findings implies that the model linking corporate growth strategies, external environment and the interaction term to firm performance was significantly fit and that corporate growth strategies, external operating environment and the interaction term contribute significantly to changes in the performance of manufacturing firms.

Table 13. Model coefficients for moderating effect

\begin{tabular}{|c|c|c|c|c|c|c|}
\hline \multirow[t]{2}{*}{ Model } & & \multicolumn{2}{|c|}{ Unstandardized Coefficients } & \multicolumn{3}{|c|}{ Standardized Coefficients } \\
\hline & & B & Std. Error & Beta & $\mathbf{t}$ & Sig. \\
\hline & (Constant) & 2.455 & 0.092 & & 26.587 & 0.000 \\
\hline 1 & Corporate Growth Strategy & 0.021 & 0.002 & 0.687 & 11.416 & 0.000 \\
\hline
\end{tabular}




\begin{tabular}{|c|c|c|c|c|c|c|}
\hline & (Constant) & 1.285 & 0.161 & & 7.959 & 0.000 \\
\hline & Corporate Growth strategy & 0.011 & 0.002 & 0.353 & 5.494 & 0.000 \\
\hline \multirow[t]{4}{*}{2} & $\begin{array}{ll}\text { External } & \text { Operating } \\
\text { Environment } & \end{array}$ & 0.461 & 0.056 & 0.529 & 8.231 & 0.000 \\
\hline & (Constant) & 2.86 & 0.436 & & 6.562 & 0.000 \\
\hline & Corporate Growth Strategy & 0.028 & 0.010 & 0.919 & 2.745 & 0.007 \\
\hline & $\begin{array}{ll}\text { External } & \text { Operating } \\
\text { Environment } & \end{array}$ & 0.059 & 0.117 & 0.068 & 0.503 & 0.616 \\
\hline 3 & Interaction Term & 0.01 & 0.003 & 1.614 & 3.864 & 0.000 \\
\hline
\end{tabular}

Dependent Variable: Firm Performance

Source: Survey data (2018)

\section{Performance of large Manufacturing Firms $=2.860+0.028$ (Corporate Growth Strategies) +0.059 (External Operating Environment) + 0.01 (Corporate Growth Strategies * External Operating Environment)}

The findings in Table 13 shows that the moderating effect of external operating environment on the relationship between corporate growth strategies and firm performance was positive and significant since the interaction term had a positive and significant beta coefficient ( Beta $=0.010, \mathrm{P}<0.000$ ). The findings corroborated findings by Henk, Niels, Ernst, Marten and Antonio (2012) that firms operating environment determined its adaptability of corporate growth strategies towards performance. The findings are also consistent with Hsiang, Hsien and Dja-Shin (2012) who established that operating environment has positive and significant impact on relationship between corporate growth strategies and firm performance. Results indicate that when the interaction of corporate growth strategies and external operating environment was introduced to the relationship between corporate growth strategies as well as external operating environment and firm performance, the effect of corporate growth strategies is increased ( from Beta $=0.011$ to 0.028 ). This implies that through interaction with the external operating environment, the effect of corporate growth strategies improves performance. The findings therefore suggest that the manufacturing firms need to analyze external operating environment in developing effective corporate growth strategies towards superior performance.

According to most of the respondents unpredictable consumer behaviour was the main challenge to the manufacturing firms. The respondents also felt that market competition and credit accessibility were other factors that pose challenges in the effectiveness of corporate strategies on firm performance.

\section{Conclusion and Recommendations}

Based on findings of this study, a combination of corporate growth strategies, competitive advantage and external operating environment on firm performance is positive and significant. The study support the proposition of the Resource Based View of the Firm that the resource value and core competencies of the firm can be used to determine the corporate grand strategies that enhances performance of the firm. It also supports the Institutional theory which contends that firms which adopt effective corporate growth strategies enhance performance by adequately addressing environmental uncertainty. The study findings were in harmony with theory, that superior firm performance results from adequate management of environmental dependencies and employing appropriate strategies to fit in the external environment, thus achieving higher performance.

Since market development strategy was found to have a positive and significant influence on firm performance, the study recommends that the firm policy makers determine markets based on profitability, geographical basis, brand royalty and customer preferences. It is also recommended that the firm policy makers develop and implement product development strategy by customizing products to suit specific customer preferences, manufacturing broad range of products to offer market choices and offer unique products for different markets. Similarly, it is recommended that firms develop and execute diversification strategy to offer market and product choices to serve larger markets to help the firms benefiting from exploiting regional market opportunities and acquire new customers.

The study established that corporate growth strategies investigated in this study explained $47.5 \%$ of performance of the large manufacturing firms indicating that other factors explain the remaining $52.5 \%$. Other studies can be conducted to establish the factors other than those tested in this study. Other future studies can also focus on other 
technically equivalent firms in other sectors other than manufacturing to provide a comparison of the findings across the sectors of economy.

\section{References}

Adeoye, A. O., \& Elegunde, A. F. (2012). Impacts of external business environment on organizational performance in the food and beverage industry in Nigeria. British Journal of Arts and Social Sciences, 6(2), 194-208.

AFDB (African Development Bank). (2016). Eastern Africa's manufacturing sector Promoting technology, innovation, productivity and linkages. Tunis.

Amue, G. J., \& Adiele, K. C. (2012). New product development and consumer innovative behaviour: An empirical validation study. European Journal of Business and Social Sciences, 1(6), 97-109.

Burns, N., \& Grove S. (2007). Understanding nursing research: Building an evidence-based practice. Journal of Advanced Nursing, 2(7), 60-96.

Chia, W. H., Wen, H., \& Heng, Y. L (2008). Corporate diversification and firm performance: The moderating role of contractual manufacturing model. Asia Pacific Management Review, 13(1), 345-360.

Chin, J., Widing, R. II, \& Paladino, A. (2004). Influence of Resource Dependency Theory on Firm Performance, Managing the Competitive Environment. University of Melbourne.

Cooper, D. R., \& Schindler. P. S. (2008). Business research methods (8th ed.). USA: McGraw-Hill.

Davis, G. F., \& Cobb, J. (2010). Resource Dependence Theory: Past and future. Research in the Sociology of Organizations, 28, 21-42. https://doi.org/10.1108/S0733-558X(2010)0000028006

DiMaggio, P. J., \& Powell, W. W. (1983). The iron cage revisited: Institutional isomorphism and collective rationality in organizational fields. American Sociological Review, 48, 147-160. https://doi.org/10.2307/2095101

Eisenhardt, K. M., \& Martin, J. A. (2000). Dynamic capabilities: what are they? Strategic Management Journal, $21(10 / 11)$, 1105-1121. https://doi.org/10.1002/1097-0266(200010/11)21:10/11<1105::AID-SMJ133>3.0.CO;2-E

Eljelly, M. A. (2004). Liquidity - Profitability Tradeoff: An empirical investigation in an emerging market. International Journal of Commerce \& Management, 14(2), 54-78. https://doi.org/10.1108/10569210480000179

Enida, P., Vasilika, K., \&Amali, C. (2015). The impact of competitive advantage on organizational performance. The evidence from Albanian context. European Scientific Journal, 11(28), 273-285.

Ezzi, F., \& Jarboui, A. (2015). Does diversification strategy affects financial, social and environmental performance companies?. International Journal of Advanced Research, 3(12), 23-38.

Faria, J. R. (2005). The game academics play: editors versus authors. Bulletin of Economic Research, 57, 1-12. https://doi.org/10.1111/j.1467-8586.2005.00212.x

Field, A. P. (2009). Discovering statistics using SPSS (2nd ed.). Sage publications.

Filbeck, G., \& Krueger, T. M. (2005). An analysis of working capital management results across industries. American Journal of Business, 20(2), 11-18. https://doi.org/10.1108/19355181200500007

Fisher, A. A., Laing, J., \& Stoeckel, J. (1985). Guidelines for overcoming design problems in family planning operations research. Studies in Family Planning, 16(2), 88-94. https://doi.org/10.2307/1965575

Foss, N. J., \& Knudsen, T. (2003). The resource-based tangle: Towards a sustainable explanation of competitive advantage. Managerial and Decision Economics, 24, 291-307. https://doi.org/10.1002/mde.1122

Foya, A. H., Kilika, J. M. \& Muathe, S. M. A. (2015). Relating technology based CRM to service quality in the telecommunications industry in Arusha city, Tanzania. Science Journal of Business and Management, 3(6), 209-218. https://doi.org/10.11648/j.sjbm.20150306.11

Furrer, O., Thomas, H., \& Gousserskaia, A. (2008). The structure and evolution of the strategic management field: A content analysis of 26 years of strategic management research. International Journal of Management Reviews, 10(1), 1-23. https://doi.org/10.1111/j.1468-2370.2007.00217.x

Grant, P., \& Perren, L. (2002). Small business and entrepreneurial research: Meta-theories, paradigms and prejudices. International Small Business Journal, 20(2), 76-93. https://doi.org/10.1177/0266242602202004 
Greenwood, R., Oliver, C., Suddaby, R., \& Sahlin-Andersson, K. (2008). The Sage Handbook of Organizational Institutionalism. Sage, London.

Hair, J. F., Money, A. H., Samouel, P., \& Page, M, (2007). Research methods for business. England: John Wiley \& Sons Ltd.

Hawawini, G., Subramanian, V., \& Verdin, P. (2003). Is performance driven industry- or firm- specific factors? A new look at the evidence. Strategic Management Journal, 24, 1-16. https://doi.org/10.1002/smj.278

Henk, W. V., Niels, W., Ernst, V., Marten, S., \& Antonio J. V. (2012). Contingency fit, institutional fit, and firm performance: A meta-fit approach to organization-environment relationships. Organization Science, 23(4), 1040-1054. https://doi.org/10.1287/orsc.1110.0687

Hidayat, R., Sabarudin, A., \& Mu'alim (2015). Effects of environmental factors on corporate strategy and performance of Manufacturing Industries in Indonesia. Journal of Industrial Engineering and Management, 8(3), 763-782. https://doi.org/10.3926/jiem.1326

Hillman, A. J., Cannella, A. A., \& Paetzold, R. L. (2000). The resource dependence role of corporate directors: Strategic adaptation of board composition in response to environmental change. Journal of Management Studies, 37, 235-256. https://doi.org/10.1111/1467-6486.00179

Hogson, A., \& Spours, K. (2008). The English education and training system: Two reform approaches of a single phase. British Educational Research Association Annual Conference, Edinburgh.

Hosseini, S. M., \& Sheikhi, N. (2012). An empirical examination of competitive capability's contribution toward firm performance: Moderating role of perceived environmental uncertainity. International Business Research, 5(5), 116-131. https://doi.org/10.5539/ibr.v5n5p116

Hsiang, F. T, Hsien, B.W., \& Dja-Shin, W. (2012). The moderating role of environmental dynamism on the influence of innovation strategy and firm performance. International Journal of Innovation, Management and Technology, 3(5), 517-520. https://doi.org/10.7763/IJIMT.2012.V3.288

Jarzabkowski, P. (2008). Shaping strategy as a structuration process. Academy of Management Journal, 51(4), 621-656. https://doi.org/10.5465/AMJ.2008.33664922

Jong, G., Phan, B., \& Ees, H. (2011). Does the meta-environment determine firm performance? Theory and evidence from European multinational enterprises. International Business Review, 20, 454-465. https://doi.org/10.1016/j.ibusrev.2010.08.003

Kavale, S. (2012). The connection between strategy and structure. International Journal of Business and Commerce, $1(6), 43-52$.

Kim, L., \& Lim, Y. (1988). Environment, generic strategies, and performance in a rapidly developing country: A taxonomic approach. Academy of Management Journal, 31(4), 802- 827. https://doi.org/10.5465/256339

Kittichai, A., \& Phapruke, U., (2010). The impacts of brand royalty strategy and marketing performance: An empirical study in garment business in Thailand. International Journal of Business Strategy, 10(4), 33.

Konar, S., \& Cohen, M. A. (2001). Does the market value environmental performance?. Review of Economics and Statistics, 83, 281-289. https://doi.org/10.1162/00346530151143815

Kothari, C. R. (2004). Research methodology: Methods and techniques (2nd ed.). New Delhi: New Age Publications.

Kutllovci, E., Shala, V., \& Troni, B. (2012). Business strategy, the Key determinants of SME growth in Kosovo. Retrieved August 25, 2018, from www.managementjournal.info

Kyengo, J. W., Ombui, K., \& Iravo, M. A. (2016). Influence of competitive strategies on the performance of telecommunication companies in Kenya. International Academic Journal of Human Resource and Business Administration, 2(1), 1-16.

Lee, J., Hall, E. H., \& Rutherford, M. W. (2003). A comparative study of U.S and Korean firms: Changes in diversification and performance. International Journal of Commerce and Management, 13(1), 11-41. https://doi.org/10.1108/eb047458

Leiblein, M. J. (2003). The choice of organizational governance form and performance: predictions from transaction cost, resource-based and real options theories. Journal of Management, 29, 937-961. https://doi.org/10.1016/S0149-2063(03)00085-0 
Lockett, A., Thompson, S., \& Morgenstern, U. (2009). The development of the resource-based view of the firm: A critical appraisal. International Journal of Management Review, 11(1), 9-28. https://doi.org/10.1111/j.1468-2370.2008.00252.x

Malhotra, N. K., \& Dash, S. (2011). Marketing Research an Applied Orientation. New Delhi: Pearson.

Mazdeh, M. M., Moradi, K., \& Mazdeh, H. M. (2011). Strategic planning model for Start-ups: A case study of Iranian packaging industry. Management Science Letters, 1, 157-166. https://doi.org/10.5267/j.msl.2010.03.005

Momoh, S. (2012). The Manufacturing Association of Nigeria (MAN) blueprint for the accelerated development of the manufacturing sector in Nigeria.

Monday, J. U., Akinola, G. O., Olegbenla, P., \& Aladeraji, O. K. (2015). Strategic management and firm performance: A study of selected manufacturing companies in Nigeria. European Journal of Business and Management, 7(2), 161-171.

Mugenda, O. M., \& Mugenda, A. G. (2003). Research methods: quantitative and approaches (4th ed.). Acts Press. Nairobi.

Myoung, P. H. (2008). Univariate analysis and normality test using SAS, Stata, and SPSS. Indiana University.

Neneh, N., \&Vanzyl, J. (2014). Growth intention and its impact on business growth amongst SMEs in South Africa. Mediterranean Journal of Social Sciences, 5(10), 172- 183. https://doi.org/10.5901/mjss.2014.v5n20p172

Newbert, S. L. (2007). Empirical research on the resource-based view of the firm: An assessment and suggestions for future research. Strategic Management Journal, 28, 121-146. https://doi.org/10.1002/smj.573

Njuguna, J. W. K., Munywoki, J., \&Kibera, F. (2014). Influence of external organizational environment and performance of community based HIV and AIDS organizations. European Scientific Journal, 10(1), 405-426.

Nybakk, E., \&Jenssen, J. I. (2012). Innovation strategy, working climate, and financial performance in traditional manufacturing firms: An empirical analysis. International Journal of Innovation Management, 16(2), 26-37. https://doi.org/10.1142/S1363919611003374

Oltra, M. J., \& Flor, M. L. (2010). The moderating effect of business strategy on the relationship between operations strategy and firms results. International Journal of Operations \& Production Management, 30(6), 612-638. https://doi.org/10.1108/01443571011046049

Ong, J. W., \& Ismail, H. B. (2012). Competitive advantage and firm performance: evidence from small and medium enterprises. International Journal of Business and Globalization, 9(2), 195-206. https://doi.org/10.1504/IJBG.2012.048960

Padachi, K. (2006). Trends in working capital management and its impact on firms' performance: An analysis of Mauritian small manufacturing firms. International Review of Business Research Papers, 2(2), 45-58.

Pasanen, M. (2003). In search of factors affecting SME performance. The case of Eastern Finland. Kuopio University Publication Business and Information Technology.

Patton, M. Q. (2002). Qualitative evaluation and research methods (3rd ed.). Thousand Oaks: Sage.

Pearce, J. A., \& Robinson, R. B. (2013). Strategic Management: Planning for Domestic and Global Competition (13th ed.). New York: McGraw-Hill Irwin.

Peteraf, M. A., \& Bergen, M. E. (2003). Scanning dynamic competitive landscapes: A market-based and resource-based framework. Strategic Management Journal, 24, 1027-1041. https://doi.org/10.1002/smj.325

Porter, M. (2008). The five competitive forces that shape strategy. Harvard Business Review, 1, 79-93.

Powell, T. C. (1996). How much industry matter? An alternative empirical test. Strategic Management Journal, 17, 323-334. https://doi.org/10.1002/(SICI)1097-0266(199604)17:4<323::AID-SMJ803>3.0.CO;2-5

Raheman, A., \& Nasri, M. (2007). Working capital management and profitability - Case of Pakistani firms. International Review of Business Research Papers, 3(2), 275-296.

Rahim, M. A., \& Magner, N. R. (2005). Confirmatory Factor Analysis of the styles of handling interpersonal conflict: Factor Model and its Intervariance across groups. Journal of Applied Psychology, 80, 122-132. https://doi.org/10.1037/0021-9010.80.1.122

Rukia, A., Mukulu, E., Kihoro, J, M., \& Waiganjo, E. W. (2015). Effect of differentiation strategy on the performance of manufacturing firms in Kenya. Asian Journal of Humanities and Social Studies, 3(2), 179-184. 
Samson, D., \& Ford, S. (2000). Manufacturing practices and performance: Comparisons between Australia and New Zealand. International Journal of Production Economics, 65, 243-255. https://doi.org/10.1016/S0925-5273(99)00076-6

Saunders, M., Lewis, P., \& Thornhill, A. (2007). Research Methods for Business Students (5th ed.). Great Britain, Prentice Hall.

Scott, W. R. (1995). Institutions and Organizations. SAGE Publications, Thousand Oaks.

Sekaran, U., \& Bougie, R. (2009). Research methods for business (5th ed.). Wiley publication.

Shapiro, S., Carlson, L., Astin, J., \& Freedman, B. (2006). Mechanisms of mindfulness. Journal of Clinical Psychology, 62, 373-86. https://doi.org/10.1002/jclp.20237

Spanos, Y. E., Zaralis, G., \&Lioukas, S. (2004). Strategy and industry effects on profitability: Evidence from Greece. Strategic Management Journal, 25(2), 139-165. https://doi.org/10.1002/smj.369

Tan, M., \& Liu, J. (2014). Paths to success: An ambidexterity perspective on how responsive and proactive market orientations affect SMEs' business performance. Journal of Strategic Marketing, 22(5), 420-441. https://doi.org/10.1080/0965254X.2013.876084

Warner, M. (2008). Reassessing human resource management with Chinese characteristics: An overview. International Journal of Human Resource Management, 19(5), 771-801. https://doi.org/10.1080/09585190801991061

Wheelen, T. L., \& Hunger, D. J. (2008). Strategic management and Business policy (11th ed.). Prentice Hall, New Jersey.

Whisman, M. A., \& MacClelland, G. H. (2005). Designing, testing, and interpreting interaction and moderator effects in family research. Journal of Family Psychology, 19(1), 111-120. https://doi.org/10.1037/0893-3200.19.1.111

World Bank. (2015). The World Bank Annual Report 2014. Washington, DC.

Yurdakul, M. (2005). Development of a performance measurement model for manufacturing companies. International Journal of Production Research, 43, 4609-4641. https://doi.org/10.1080/00207540500161746

Zikmund, W. (2003). Exploring Marketing Research (7th ed.). USA. Thompson, South Western. 